of hull, from the flatness of bottom and fullness of ends ; (2) weakness of action of rudder, from its position in the clead-water; (3) an active turning force, consisting in a one-sided pressure on the stern arising out of a onesided system of flow in the water closing in behind the full run. It was principally to the last-mentioned cause that Mr. Froude, when called upon to investigate the case of the Ajax, was inclined to attribute the behaviour of the ship, such a phenomenon having been some years since incidentally observed in the course of experiments made in the experiment tank at Torquay on the resistance of a model having a full run. In this case a lateral force was found to be developed upon the stern of the model, accompanied by a trailing away of the wake to one side, and a transverse flow of the water across behind the stern, in the opposite direction to that in which the lateral force was developed. This one-sidedness of flow, and consequent force (like the helm tendency of the Ajax), was sometimes in one clirection, and sometimes in the other, and occasionally reversed its direction during any experiment : but was generally more or less persistent in direction when initiated, although the direction in which it was initiated was apparently a matter of accident. It was Mr. Froude's belief, founded on these and many other experiments of various kinds, that this species of, so to speak, spasmodic one-sidedness of flow, and consequent one-sided force, attends the motion of all, even perfectly symmetrical, bodies through water, whenever their leaving lines are blunt enough to cause a large eddy behind them.

By way of a method of experiment suitable to test the effect of remedies designed to mitigate or remove either of the three presumable causes of the behaviour of the ship, which have been enumerated above, Mr. Froude towed a model of the $A j a x$ in the experiment tank at Torquay, the model being attached to the towing carriage in such a way that, while the model was free to sheer out of the straight course, any such attempted sheering motion actuated a working rudder fitted to the model, in the proper direction for frustrating the attempt. By this contrivance the model was made to steer quite straight, and the criterion of the badness of the steering qualities of the model in the several conditions of trial subjected to experiment, was the amount and the degree of unsteadiness of the helm angle administered, this helm angle being continuously recorded throughout each experiment by an automatic apparatus. Thus tested, the model was found to exhibit conspicuously what has been referred to as the predominant characteristic of the behaviour of the ship, viz. the large helm angle, sometimes persistently on one side, sometimes on the other, and occasionally changing from one side to the other.

The principal remedies tentatively applied to the model with a view to identifying the main source of the evil, and indicating the direction in which improvement was to be sought, were these : (I) a deep keel, to supply "the directive character" in which the hull itself was presumably lacking ; (2) placing the rudder altogether below the keel, so as to be quite clear of the dead-water; (3) an extensive deadwood (or fixed rudder) behind the stern-post, (the working rudder being still below the keel), to frustrate the onesided flow behind the stern, and do away with the consequent turning force. Of these three kinds of remedy the last-named proved much the most effective, proved indeed an almost perfect cure, thereby confirming the surmise that the one-sided flow at the stern was the chief source of the evil. A minor modification of this dead-wood, with the rudder in its proper place, such as could be practically applied in the ship, likewise proved very tolerably effective, the average helm angle required being reduced to one-third of its amount.

On the strength of the results of these experiments, the Admiralty added a structure of this kind to the stern of the ship, with a result which, while it was a remarkable corro- boration of the model experiments, was also on the whole a decided isuccess from a practical point of view, the reduction effected in angle of helm being quite sufficient to qualify the ship to steam at full speed in a squadron and keep station satisfactorily.

\section{EDWARD T. HARDMAN}

B the unexpected death of this geologist, on the 30 th uIt., Irish Science has been deprived of one of her most promising followers. Mr. Hardman was born in Drogheda in 1845 , and distinguished himself by the position he took at the Grammar School there, gaining a Government Exhibition and an entrance to the Royal College of Science in Dublin. He soon displayed his strong natural bent towards scientific pursuits, and when he quitted the College he had gained its diploma of Associate and taken a prominent place among its foremost students, more particularly in the departments of chemistry and geology. In I 870 he was appointed to the Geological Survey, and threw himself with characteristic ardour into the prosecution of field-work, while his knowledge of chemistry and mineralogy led to his being employed in special services where this knowledge was made available in the work of the Survey. His reports on the Tyrone and Kilkenny coal-fields are good examples of the extent of his knowledge and of his powers of literary expression. $\mathrm{He}$ also made his mark by the publication of papers outside the limits of official work. His interesting and suggestive memoir on the origin of Lough Neagh and his papers on anthracite and chert are well known.

In I 883 the Government of Western Australia applied to the Colonial Office for the services of a trained geologist to examine and report on the mineral resources and geological structure of the colony. Mr. Hardman was selected for the post, and obtained leave of absence from the Home Government to enable him to undertake the duties. He was absent upwards of two years, during which time he effected a preliminary survey of a wide tract of unexplored country, and made known its geological structure. In particular, he indicated the presence of gold, and pointed out the areas where gold-fields might be looked for. After enduring great hardships in the bush, he returned to this country, and resumed his duties in the Geological Survey. But the exposure in the Australian climate seems to have told upon his health. $\mathrm{He}$ had not been quite well during the spring, and at last he rapidly fell a victim to an attack of typhoid fever. We understand that arrangements had been nearly completed for recalling him permanently to take charge of the mineral surveys of Western Australia, when his sudden death occurred. He has left a widow and two children with no adequate provision, and his friends have already begun to take steps for collecting subscriptions for their behoof. Prof. V. Ball, of the Science and Art Museum, Dublin, and Dr. Henry Woodward, of the Natural History Department of the British Museum, Cromwell Road, S.W., have kindly undertaken to receive subscriptions.

\section{NOTES.}

The Natural History branch of the British Museum in Cromwell Road has just received a most important donation from Lord Walsingham, consisting of a collection of Lepidoptera with their larva, mainly British butterflies (Rhopalocera) and certain families of moths (Helerocera), including Sphingide, Bombyces, Psendobombyces, Ncctue, Geometride, and Pyralidee. There is also a fine series of Inclian species, collected and preserved at Dharmsala, in the Punjab, by the Rev. Jobn $\mathrm{H}$. Hocking, and specimens of exotic silk-producing Bombyces in 